\title{
PENGARUH PEMBELAJARAN E-LEARNING MENGGUNAKAN PLATFORM SCHOOLOGY PADA MATERI IPA (PENCEMARAN LINGKUNGAN) TERHADAP KEMANDIRIAN BELAJAR DAN HASIL BELAJAR SISWA SMP
}

\author{
Lailatul Istimewa $^{1}$, Indrawati ${ }^{2}$, Iwan Wicaksono ${ }^{3}$ \\ Fakultas Keguruan dan Ilmu Pendidikan, Universitas Jember \\ e-mail: lailatulistimewa@gmail.com
}

\section{ABSTRAK}

Penelitian ini bertujuan untuk mengkaji pengaruh pembelajaran e-learning menggunakan platform Schoology pada materi IPA khususnya pencemaran lingkungan terhadap kemandirian belajar dan hasil belajar siswa Sekolah Menengah Pertama. Penelitian ini merupakan jenis penelitian kuasi eksperimen dengan desain nonequivalent control group design. Sampel ditentukan menggunakan metode purposive sampling sesuai kriteria yang ditentukan peneliti yaitu kelas VII E sebagai kelas eksperimen dan VII D sebagai kelas kontrol. Waktu pelaksanaan penelitian pada semester genap tahun ajaran 2020/2021. Data yang diperoleh dianalisis menggunakan uji statistik berupa uji normalitas, uji independent sample t test, uji Mann Whitney U Test, dan uji $\mathrm{t}$ - pihak kanan. Instrumen yang digunakan untuk mengukur kemandirian belajar menggunakan lembar angket dan untuk mengukur hasil belajar menggunakan lembar tes pada penilaian ranah pengetahuan sedangkan penilaian ranah keterampilan menggunakan non tes berupa pembuatan laporan tertulis. Hasil analisis data pada kemandirian belajar tidak berdistribusi normal sehingga dilanjutkan menggunakan uji Mann Whitney U Test diperoleh nilai signifikansi $0,000<0,05$ yang artinya ada perbedaan kemandirian belajar siswa antara kelas eksperimen dan kelas kontrol setelah pembelajaran $e$ learning menggunakan platform Schoology. Hasil analisis data pada hasil belajar berdistribusi normal sehingga dilanjutkan uji homogenitas. Hasil uji homogenitas pada ranah pengetahuan 0,118>0,05 yang artinya data homogen, sedangkan pada ranah keterampilan sebesar $0,004<0,05$ yang artinya data tidak homogen. Analisis data selanjutnya menggunakan uji independent sample $t$ test diperoleh nilai signifikansi $0,000<0,05$ pada ranah pengetahuan dan $0,025<0,05$ pada ranah keterampilan yang artinya ada perbedaan hasil belajar siswa antara kelas eksperimen dan kelas kontrol karena pembelajaran e-learning menggunakan platform Schoology.

Kata Kunci: Schoology, kemandirian belajar, hasil belajar

\section{ABSTRACT}

This study aims to examine the effect of e-learning using the Schoology platform on science material, especially environmental pollution on independent learning and learning outcomes of junior high school students. This research is a quasi-experimental research with a nonequivalent control group design. The sample was determined using the purposive sampling method according to the criteria determined by the researcher, namely class VII E as the experimental class and VII D as the control class. The research implementation time is 
in the even semester of the 2020/2021 academic year. The data obtained were analyzed using statistical tests in the form of normality test, independent sample t test, Mann Whitney U test, and right side t test. The instrument used to measure learning independence was using a questionnaire sheet and to measure learning outcomes using a test sheet on the assessment of the realm of knowledge while the assessment of the realm of skills used a non-test in the form of making a written report. The results of data analysis on learning independence were not normally distributed, so it was continued using the Mann Whitney U Test, a significance value of $0.000<0.05$ was obtained, which means that there was a difference in student learning independence between the experimental class and the control class after e-learning using the Schoology platform. The results of data analysis on learning outcomes are normally distributed so that the homogeneity test is continued. The results of the homogeneity test in the knowledge domain are $0.118>0.05$, which means the data is homogeneous, while in the skill domain it is $0.004<0.05$, which means the data is not homogeneous. Further data analysis using the independent sample t test obtained a significance value of $0.000<0.05$ in the knowledge domain and $0.025<0.05$ in the skills domain, which means that there is a difference in student learning outcomes between the experimental class and the control class because e-learning uses the Schoology platform.

\section{Keywords: Schoology, independent learning, learning outcomes}

\section{PENDAHULUAN}

Ilmu Pengetahuan Alam (IPA) ialah rumpun ilmu yang mempelajari alam semesta dan gejala-gejalanya. Yani et al. (2019:173) mendefinisikan bahwa IPA adalah ilmu yang berhubungan dengan fenomena alam pada kehidupan sehari-hari dan interaksi yang terjadi di dalamnya. Dinatha dan Laksana (2017:179) mengatakan bahwa IPA mengkaji alam semesta, yang melewati serangkaian proses ilmiah untuk mendapatkan sebuah produk sehingga mampu terbentuk sebuah sikap ilmiah. Pembelajaran IPA menuntun siswa untuk berperan aktif dan terlibat secara langsung (Nurbani, 2016:212). Hal tersebut sesuai dengan pendapat Handayanti et al. (2020:64) yang menjelaskan bahwa pembelajaran IPA menuntun siswa untuk pemberian pengalaman langsung dalam mengembangkan kompetensi siswa agar mampu menjelajahi serta memahami alam sekitar. Pertiwi et al. (2018:26) menyatakan bahwa pembelajaran IPA mampu diperoleh dengan menghubungkan konsep kehidupan sehari-hari dengan konsep yang sedang dipelajari siswa. Ketika pembelajaran berlangsung, tidak jarang dijumpai siswa yang kesulitan memahami konsep materi yang diajarkan, sehingga siswa mengalami rasa kurang percaya diri dan pesimis dalam belajar IPA. Kondisi tersebut dapat menimbulkan kurangnya kemandirian belajar siswa yang dapat berpengaruh pada hasil belajar siswa.

Kemandirian belajar memiliki peranan penting bagi siswa karena dapat memupuk rasa percaya diri dan lebih mudah untuk memahami materi pembelajaran sehingga karakter siswa dapat terwujud lebih baik. Bungsu et al. (2019:383) menyatakan bahwa pada kenyataannya, terdapat siswa yang belum memiliki inisiatif untuk belajar selain sumber yang diberikan oleh guru, sedangkan siswa memiliki sumber belajar lain seperti buku materi pelajaran, internet, dan lainnya yang mampu dipelajari secara mandiri di luar sekolah. Apabila kemandirian belajar siswa rendah maka kurang memiliki sikap tanggung jawab pada tugas yang diberikan guru dan masih mengandalkan bantuan orang lain, hal tersebut berpengaruh pada kurang 
optimalnya hasil belajar. Juniati \& Widiana (2017:21) secara umum menjelaskan bahwa terdapat beberapa hal yang menjadi penyebab kurang optimalnya hasil belajar siswa, di antaranya yaitu: 1) guru ketika mengajar hanya memakai satu sumber belajar, 2) aktivitas siswa pasif, 3) mayoritas siswa memandang IPA merupakan pelajaran yang cukup rumit, membosankan, serta menghafal, 4) kurang terbiasanya siswa bekerja secara kelompok. Diperlukan pengelolaan kelas yang menarik untuk menambah semangat siswa dalam mengikuti pembelajaran IPA. Wicaksono et al. (2015:519) menyatakan bahwa proses pembelajaran ialah salah satu tahap yang berperan penting dalam keberhasilan belajar siswa.

Berdasarkan obeservasi awal peneliti, siswa pada sekolah tersebut masih belum terbiasa melakukan pembelajaran secara e-learning. Siswa masih cenderung pasif ketika pembelajaran berlangsung dan belum bisa sepenuhnya mandiri dalam mengikuti pembelajaran, hal ini menjadikan siswa kurang bertanggung jawab atas tugas-tugas yang diberikan oleh guru. Siswa yang pasif akan kurang semangat dan mudah bosan dalam mengikuti pembelajaran, hal tersebut dapat berpengaruh pada hasil belajar. Dengan demikian, perlu adanya sebuah inovasi pembelajaran dengan memanfaatkan platform yang menarik, sehingga siswa tidak mudah bosan dan dapat mengikuti pembelajaran secara optimal. Pengelolaan kelas yang menarik dapat memanfaatkan berbagai macam jenis Learning Management System (LMS). Salah satu LMS yang dapat diterapkan dalam pembelajaran jarak jauh ialah Schoology. Schoology adalah salah satu laman web yang menyediakan pembelajaran hampir sama seperti di dalam kelas (Ulva, 2017:97). Fitur-fitur yang terdapat pada Schoology diantaranya yaitu courses (kursus) yang berfungsi untuk membuat kelas mata pelajaran, groups (kelompok) yang berfungsi membuat kelompok, resources (sumber belajar) yang di dalamnya guru dapat menyajikan materi seperti file/link, image, assignment, test/quiz, page, dan discussion. Sumber belajar seperti video, slide presentasi, diskusi, tes, kuis juga dapat diakses melalui Schoology sehingga siswa memiliki berbagai macam sumber belajar (Murni \& Harimurti, 2016:87). Hal tersebut sesuai dengan pernyataan Erviani et al. (2016:54) bahwa pembelajaran yang secara aktif siswa dapat bertindak salah satunya dengan memberikan penugasan, yang mana siswa akan menelaah informasi secara mandiri dari sumber-sumber belajar yang tersedia dan jaringan-jaringan informasi lainnya.

Penelitian ini memberikan perlakuan terbaru untuk siswa agar mengikuti pembelajaran secara optimal. Perlakuan ini dengan cara pembelajaran e-learning dengan memanfaatkan platform Schoology yang diterapkan kepada siswa disertai penugasan yang menuntun siswa untuk menggali pengetahuannya di lingkungan sekitar secara mandiri. Peneliti juga menyediakan berbagai macam referensi pembelajaran pada Schoology seperti video pembelajaran, link, file, dan lain sebagainya sehingga siswa memiliki sumber belajar yang bervariasi.

\section{METODE}

Jenis penelitian yang digunakan yaitu kuasi eksperimen dengan teknik penentuan sampel menggunakan purposive sampling area. Jenis penelitian ini dipilih karena peneliti tidak dapat secara penuh mengontrol variabel-variabel luar yang mempengaruhi penelitian. Pertimbangan lainnya karena menyesuaikan karakteristik penelitian seperti fasilitas yang dimiliki siswa, jaringan yang mendukung siswa dalam mengikuti pembelajaran, serta materi pelajaran yang digunakan belum diajarkan pada kelas tersebut. Penelitian ini 
dilaksanakan di SMP Negeri 1 Dongko pada semester genap tahun ajaran 2020/2021. Teknik pengumpulan data untuk kemandirian belajar menggunakan angket kemandirian belajar sebanyak 25 item pertanyaan yang disesuaikan dengan indikator kemandirian belajar. Sedangkan teknik pengumpulan data untuk hasil belajar menggunakan soal tes pada ranah pengetahuan berupa soal pilihan ganda dan uraian serta non tes pada ranah keterampilan berupa penugasan yang telah disesuaikan dengan indikator pembelajaran.

Teknik analisis data yang digunakan pada kedua variabel terlebih dahulu diuji normalitasnya. Apabila data berdistribusi normal dapat dilanjutkan menggunakan uji homogenitas kemudian uji independent sample t test sedangkan jika data tidak berdistribusi normal dapat dilanjutkan menggunakan uji Mann Whitney U Test. Apabila telah diketahui terdapat perbedaan rata-rata kelas eksperimen dan kontrol, dapat dilanjutkan dengan uji t pihak kanan. Desain penelitian yang digunakan yaitu nonequivalent control group design dengan penentuan kelas eksperimen dan kelas kontrol tidak dipilih secara acak.

\begin{tabular}{|c|c|c|c|}
\hline Kelas & Pretest & Perlakuan & Posttest \\
\hline Eksperimen & $\mathrm{O}_{1}$ & $\mathrm{X}$ & $\mathrm{O}_{2}$ \\
\hline Kontrol & $\mathrm{O}_{3}$ & & $\mathrm{O}_{4}$ \\
\hline
\end{tabular}

(Karlina et al., 2018:55)

Gambar 1. Nonequivalent control group design

Keterangan:

$\mathrm{O}_{1}$ : Pretest (tes awal) kelas eksperimen

$\mathrm{O}_{2}$ : Posttest (tes akhir) kelas eksperimen

$\mathrm{O}_{3}$ : Pretest (tes awal) kelas kontrol

$\mathrm{O}_{4}$ : Posttest (tes akhir) kelas kontrol

$\mathrm{X}$ : Perlakuan terhadap kelas eksperimen

Hipotesis statistik yang diajukan untuk kemandirian belajar dalam penelitian sebagai berikut:

$\mathrm{H}_{0}$ : tidak terdapat perbedaan rata-rata kemandirian belajar siswa pada kelas eksperimen dan kelas kontrol

$\mathrm{H}_{1}$ : terdapat perbedaan rata-rata kemandirian belajar siswa pada kelas eksperimen dan kelas kontrol

Hipotesis statistik yang diajukan untuk hasil belajar dalam penelitian sebagai berikut:

$\mathrm{H}_{0}$ : tidak terdapat perbedaan rata-rata hasil belajar siswa ranah pengetahuan pada kelas eksperimen dan kelas kontrol

$\mathrm{H}_{1}$ : terdapat perbedaan rata-rata hasil belajar siswa ranah pengetahuan pada kelas eksperimen dan kelas kontrol

Uji hipotesis selanjutnya yaitu uji $\mathrm{t}$ - pihak kanan. Uji $\mathrm{t}$ - pihak kanan digunakan jika $\mathrm{H}_{0}$ berbunyi lebih kecil atau sama dengan $(\leq)$ dan $\mathrm{H}_{1}$ berbunyi lebih besar $(>)$. Berdasarkan hipotesis penelitian yang telah diuraikan sebelumnya, maka diperlukan hipotesis statistik dalam pengujian sampel penelitian. Sebelum melakukan uji $\mathrm{t}$ - pihak kanan, perlu diketahui hipotesis statistik penelitian sebagai berikut:

$\mathrm{H}_{0}: \mathrm{R}_{1} \leq \mathrm{R}_{2}$ (nilai rata-rata kelas eksperimen tidak lebih baik dibandingkan dengan kelas kontrol)

$\mathrm{H}_{1}: \mathrm{R}_{1}>\mathrm{R}_{2}$ (nilai rata-rata kelas eksperimen lebih baik dibandingkan dengan kelas kontrol) 
Keterangan:

$\mathrm{R}_{1}$ : Kelas eksperimen

$\mathrm{R}_{2}$ : Kelas kontrol

Kemudian perlu diketahui kriteria uji statistik sebagai dasar pengambilan keputusan pada uji $\mathrm{t}$ - pihak kanan sebagai berikut:

a. Jika $t_{\text {hitung }}<\mathrm{t}_{\text {tabel }}$ maka $\mathrm{H}_{0}$ (hipotesis nihil) diterima dan $\mathrm{H}_{1}$ (hipotesis alternatif) ditolak

b. Jika $\mathrm{t}_{\text {hitung }}>\mathrm{t}_{\text {tabel }}$ maka $\mathrm{H}_{0}$ (hipotesis nihil) ditolak dan $\mathrm{H}_{1}$ (hipotesis alternatif) diterima.

\section{HASIL DAN PEMBAHASAN}

Data yang diperoleh dari penelitian ini berupa kemandirian belajar serta hasil belajar siswa pada ranah pengetahuan dan keterampilan. Data kemandirian belajar siswa diperoleh dari angket kemandirian belajar. Data rekapitulasi kemandirian belajar siswa dalam mengisi angket kemandirian belajar pada kelas eksperimen dan kelas kontrol dapat dilihat pada Tabel 1.

Tabel 1. Rekapitulasi data kemandirian belajar siswa

\begin{tabular}{|c|c|c|c|c|}
\hline \multirow{2}{*}{ Komponen } & \multicolumn{2}{|c|}{ Kelas Eksperimen } & \multicolumn{2}{c|}{ Kelas Kontrol } \\
\cline { 2 - 5 } & Angket Awal & Angket Akhir & Angket Awal & Angket Akhir \\
\hline Nilai tertinggi & 94 & 94 & 87 & 85 \\
\hline Nilai terendah & 37 & 46 & 37 & 38 \\
\hline Rata - rata & 60 & 83 & 49 & 58 \\
\hline
\end{tabular}

Berdasarkan Tabel 1 dapat diketahui perolehan skor rata-rata kelas eksperimen dan kelas kontrol. Kelas eksperimen memiliki skor rata-rata kemandirian belajar lebih tinggi jika dibandingkan dengan kelas kontrol. Data kemandirian belajar yang telah dikumpulkan selanjutnya dilakukan uji normalitas pada pengisian angket awal dan akhir menggunakan uji Shapiro-Wilk dengan bantuan software SPSS. Jika data berdistribusi normal maka dilanjutkan uji homogenitas dan uji parametrik menggunakan uji independent sample t test, sedangkan apabila data tidak berdistribusi normal maka dilanjutkan uji non parametrik menggunakan uji Mann Whitney U Test. Output uji normalitas pengisian angket kemandirian belajar awal dan akhir dapat dilihat pada Tabel 2.

Tabel 2. Test of Normality

\begin{tabular}{|c|l|c|c|c|c|c|c|}
\hline \multirow{2}{*}{ Kelas } & \multicolumn{3}{|c|}{\begin{tabular}{c} 
Kolmogorov- \\
\multicolumn{3}{|c|}{ Smirnov $^{\mathrm{a}}$}
\end{tabular}} & \multicolumn{3}{c|}{ Shapiro-Wilk } \\
\cline { 3 - 8 } & & Statistic & df & Sig. & Statistic & df & Sig. \\
\hline \multirow{2}{*}{$\begin{array}{c}\text { Angket } \\
\text { Kemandirian } \\
\text { Belajar } \\
\text { Siswa }\end{array}$} & Angket Awal Eksperimen & .268 & 20 & .001 & .889 & 20 & .026 \\
\cline { 2 - 8 } & Angket Akhir Eksperimen & .254 & 20 & .002 & .717 & 20 & .000 \\
\cline { 2 - 8 } & Angket Awal Kontrol & .380 & 20 & .000 & .692 & 20 & .000 \\
\cline { 2 - 8 } & Angket Akhir Kontrol & .144 & 20 & $.200^{*}$ & .929 & 20 & .145 \\
\hline
\end{tabular}

Berdasarkan Tabel 2 diperoleh nilai signifikansi pada pengisian angket awal dan akhir kelas eksperimen serta angket awal kontrol lebih kecil dari 0,05 sehingga data kemandirian belajar tidak berdistribusi normal. Sedangkan pada angket akhir kelas kontrol lebih besar dari 0,05 sehingga data berdistribusi normal. Dengan demikian, dilanjutkan uji non parametrik 
menggunakan uji Mann Whitney U Test yang bertujuan untuk mengetahui ada tidaknya perbedaan yang signifikan dari pengisian angket awal dan akhir pada kelas eksperimen dan kelas kontrol.

Tabel 3. Mann Whitney U Test

\begin{tabular}{|l|r|}
\hline & \multicolumn{1}{|c|}{$\begin{array}{c}\text { Angket } \\
\text { Kemandirian } \\
\text { Belajar Siswa }\end{array}$} \\
\hline Mann-Whitney U & 46.000 \\
\hline Wilcoxon W & 256.000 \\
\hline$Z$ & -4.169 \\
\hline Asymp. Sig. (2-tailed) & .000 \\
\hline $\begin{array}{l}\text { Exact Sig. [2*(1-tailed } \\
\text { Sig.)] }\end{array}$ & $.000^{\text {b }}$ \\
\hline
\end{tabular}

Berdasarkan hasil uji Mann Whitney U Test pada Tabel 3 dapat dilihat nilai Asymp. Sig. (2-tailed) sebesar 0,000 yang artinya nilai signifikansi $<0,05$ sehingga $\mathrm{H}_{0}$ ditolak dan $\mathrm{H}_{1}$ diterima. Dengan demikian dapat disimpulkan bahwa ada perbedaan kemandirian belajar siswa antara kelas eksperimen dan kelas kontrol karena pembelajaran e-learning menggunakan platform Schoology. Pernyataan tersebut sesuai dengan penelitian Misbah et al. (2018:114) menyatakan bahwa Schoology efektif digunakan dalam pembelajaran karena mudah digunakan dan dapat diakses siswa di dalam maupun luar pembelajaran. Selain itu, siswa dapat mengakses berbagai file yang tersedia di Schoology misalnya materi pelajaran, video, gambar, hingga praktikum virtual. Penelitian sejenis yang dilakukan oleh Tsaniyah et al. (2019:75) menyimpulkan bahwa siswa dengan kemandirian belajar tinggi yang menggunakan Schoology cenderung dapat belajar lebih baik, dapat memantau, mengevaluasi, serta memanajemen jadwal belajarnya seefisien mungkin serta senantiasa bersaing untuk menunjukkan hasil yang terbaik. Mayasari et al. (2016:149) dalam penelitiannya juga menyatakan bahwa siswa yang memiliki kemandirian belajar yang tinggi maka akan mampu berpikir kritis pada suatu topik ataupun masalah lalu mencari solusi dari permasalahan tersebut.

Data hasil belajar terdiri dari ranah pengetahuan dan keterampilan. Data pada ranah pengetahuan diperoleh dari tes, yang mana berupa pemberian soal pre-test dan post-test. Soal tes yang diberikan berupa 10 soal pilihan ganda dan 5 soal uraian, soal-soal tersebut telah disesuaikan dengan indikator-indikator hasil belajar dengan ranah pengetahuan Rekapitulasi data hasil belajar siswa dalam menyelesaikan pre-test dan post-test pada kelas eksperimen dan kelas kontrol dapat dilihat pada Tabel 4.

Tabel 4. Rekapitulasi data tes hasil belajar siswa

\begin{tabular}{|c|c|c|c|c|}
\hline \multirow{2}{*}{ Komponen } & \multicolumn{2}{|c|}{ Kelas Eksperimen } & \multicolumn{2}{c|}{ Kelas Kontrol } \\
\cline { 2 - 5 } & Pre-test & Post-test & Pre-test & Post-test \\
\hline Nilai tertinggi & 68 & 88 & 59 & 66 \\
\hline Nilai terendah & 29 & 46 & 22 & 32 \\
\hline Rata - rata & 52 & 70 & 40 & 51 \\
\hline
\end{tabular}

Berdasarkan Tabel 4 menunjukkan perolehan skor rata-rata antara kelas eksperimen 
dan kelas kontrol. Kelas eksperimen memiliki rata-rata tes hasil belajar lebih tinggi dibandingkan kelas kontrol. Data hasil belajar pada ranah pengetahuan selanjutnya dilakukan uji normalitas. Apabila data berdistribusi normal maka dilanjutkan ke uji homogenitas dan uji parametrik menggunakan uji independent sample $t$ test sedangkan apabila data tidak berdistribusi normal dilanjutkan ke uji non parametrik menggunakan uji Mann Whitney $U$ Test. Output uji normalitas terhadap hasil belajar siswa pada ranah pengetahuan dapat dilihat pada Tabel 5.

Tabel 5. Test of Normality

\begin{tabular}{|c|l|c|c|c|c|c|c|}
\hline \multirow{2}{*}{ Kelas } & \multicolumn{3}{|c|}{$\begin{array}{c}\text { Kolmogorov- } \\
\text { Smirnov }\end{array}$} & \multicolumn{3}{c|}{ Shapiro-Wilk } \\
\cline { 3 - 8 } & & Statistic & df & Sig. & Statistic & df & Sig. \\
\hline \multirow{4}{*}{$\begin{array}{c}\text { Hasil Belajary } \\
\text { Siswa }\end{array}$} & Pre-Test Eksperimen & .109 & 20 & $.200^{*}$ & .954 & 20 & .429 \\
\cline { 2 - 8 } & Post-Test Eksperimen & .135 & 20 & $.200^{*}$ & .954 & 20 & .431 \\
\cline { 2 - 8 } & Pre-Test Kontrol & .108 & 20 & $.200^{*}$ & .957 & 20 & .492 \\
\cline { 2 - 8 } & Post-Test Kontrol & .150 & 20 & $.200^{*}$ & .960 & 20 & .540 \\
\hline
\end{tabular}

Berdasarkan Tabel 5 diperoleh nilai signifikan baik pada kelas eksperimen maupun kelas kontrol lebih besar dari 0,05 sehingga dapat dikatakan bahwa data berdistribusi normal. Selanjutnya dilakukan uji independent sample $t$ test untuk mengetahui ada tidaknya perbedaan yang signifikan antara nilai pre-test dan post-test kelas eksperimen dan kelas kontrol.

Output uji independent sample t test dapat dilihat pada Tabel 6.

Tabel 6. Output Independent Samples Test

\begin{tabular}{|c|c|c|c|c|c|c|c|}
\hline \multicolumn{8}{|c|}{ Independent Sample T-test } \\
\hline \multirow{4}{*}{$\begin{array}{c}\text { Hasil } \\
\text { Belajar } \\
\text { Siswa }\end{array}$} & & $\begin{array}{r}\text { Levene } \\
\text { for Equ } \\
\text { Vari }\end{array}$ & $\begin{array}{l}\text { Test } \\
\text { ty of } \\
\text { es }\end{array}$ & \multicolumn{4}{|c|}{ t-test for Equality of Means } \\
\hline & & $\mathrm{F}$ & Sig. & $\mathrm{t}$ & df & $\begin{array}{l}\text { Sig. (2- } \\
\text { tailed) }\end{array}$ & $\begin{array}{c}\text { Mean } \\
\text { Differenc } \\
\text { e }\end{array}$ \\
\hline & Equal variances assumed & 2.553 & .118 & 5.571 & 38 & .000 & 19.050 \\
\hline & $\begin{array}{l}\text { Equal variances not } \\
\text { assumed }\end{array}$ & & & 5.571 & $\begin{array}{c}35.5 \\
19\end{array}$ & .000 & 19.050 \\
\hline
\end{tabular}

Berdasarkan hasil uji independent sample t test pada Tabel 6 diperoleh nilai signifikansi (Sig.) pada kolom Levene's Test for Equality of Variances sebesar 0,118 sehingga dapat dikatakan data pre-test dan post-test bersifat homogen. Tahap selanjutnya yaitu membaca kolom $t$-test for Equality of Means yang menunjukkan bahwa nilai Sig. (2-tailed) sebesar 0,000 yang artinya nilai signifikansi $<0,05$ sehingga $\mathrm{H}_{0}$ ditolak dan $\mathrm{H}_{1}$ diterima. Dengan demikian dapat disimpulkan bahwa ada perbedaan hasil belajar siswa pada ranah pengetahuan antara kelas eksperimen dan kelas kontrol karena pembelajaran e-learning menggunakan platform Schoology. Setelah mengetahui data terdapat perbedaan, selanjutnya perlu dilakukan uji $\mathrm{t}$ - pihak kanan dengan hipotesis statistik dan kriteria uji statistik seperti 
yang diuraikan pada bab sebelumnya. Hasil uji t - pihak kanan pada hasil belajar ranah pengetahuan dapat dilihat pada Tabel 7.

Tabel 7. Hasil uji $\mathrm{t}$ - pihak kanan hasil belajar ranah pengetahuan

\begin{tabular}{|c|c|c|c|}
\hline Kelas & Rata-rata & $\mathrm{t}_{\text {hitung }}$ & $\mathrm{t}_{\text {tabel }}$ \\
\hline Kelas Eksperimen & 70 & \multirow{2}{*}{5.571} & \multirow{2}{*}{1.686} \\
\cline { 1 - 2 } Kelas Kontrol & 51 & & \\
\hline
\end{tabular}

Tabel 7 menunjukkan bahwa diperoleh uji $\mathrm{t}$ - pihak kanan hasil belajar ranah pengetahuan. Nilai $t_{\text {tabel }}$ pada tabel distribusi t dengan taraf signifikansi 0,05 sebesar 1,686, sedangkan hasil perhitungan untuk $t_{\text {hitung }}$ sebesar 5,571. Hasil perhitungan tersebut menunjukkan bahwa $t_{\text {hitung }}>t_{\text {tabel }}$ maka dapat dinyatakan bahwa $\mathrm{H}_{0}$ ditolak dan $\mathrm{H}_{1}$ diterima yang artinya nilai rata-rata kelas eksperimen lebih baik dibandingkan dengan kelas kontrol.

Data pada ranah keterampilan diperoleh dari penugasan (non tes) berupa penulisan laporan tertulis. Penugasan diberikan setiap pertemuan dan penyelesaiannya dalam waktu tertentu. Penugasan yang diberikan telah disesuaikan dengan ranah keterampilan dengan tingkat keterampilan menyesuaikan Kompetensi Dasar (KD) yang sudah ada. Data hasil belajar siswa dalam ranah keterampilan pada kelas eksperimen dan kelas kontrol dapat dilihat pada Tabel 8.

Tabel 8. Rata-rata hasil belajar siswa ranah keterampilan

\begin{tabular}{|c|c|c|c|}
\hline No & Kelas & $\begin{array}{c}\text { Rata-rata keterampilan } \\
\text { siswa }\end{array}$ & Kategori \\
\hline 1 & Kontrol & 63 & Cukup \\
\hline 2 & Eksperimen & 72 & Baik \\
\hline
\end{tabular}

Berdasarkan rata-rata hasil belajar siswa pada ranah keterampilan, maka dapat dibuat diagram seperti pada Gambar 2.

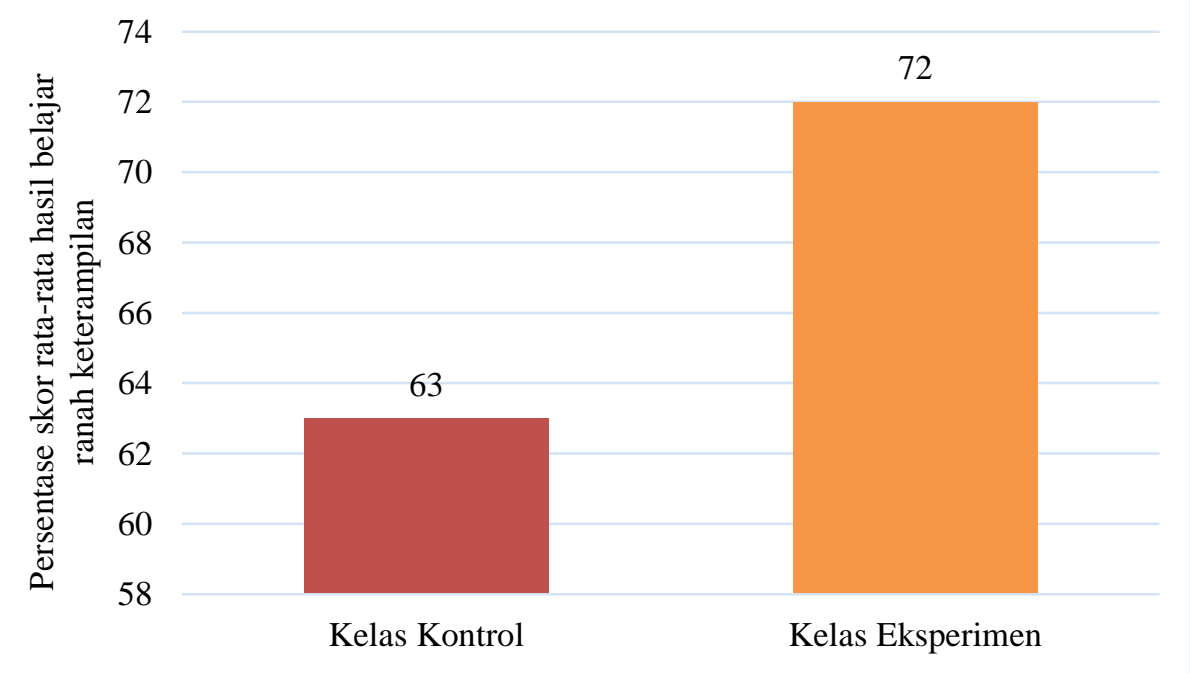

Gambar 2. Persentase skor rata-rata hasil belajar ranah keterampilan

Berdasarkan Gambar 2 menunjukkan persentase skor rata-rata hasil belajar ranah keterampilan antara kelas eksperimen dan kelas kontrol. Kelas eksperimen memiliki rata-rata tes hasil belajar lebih tinggi dibandingkan kelas kontrol. Selanjutnya melakukan uji 
normalitas pada data hasil belajar ranah keterampilan. Output uji normalitas terhadap hasil belajar siswa pada ranah keterampilan dapat dilihat pada Tabel 9.

Tabel 9. Test of Normality

\begin{tabular}{|c|l|c|c|c|c|c|c|}
\hline \multirow{2}{*}{} & \multirow{2}{*}{ Kelas } & \multicolumn{3}{|c|}{$\begin{array}{c}\text { Kolmogorov- } \\
\text { Smirnov }^{\mathrm{a}}\end{array}$} & \multicolumn{3}{c|}{ Shapiro-Wilk } \\
\cline { 3 - 8 } & & Statistic & df & Sig. & Statistic & df & Sig. \\
\hline $\begin{array}{c}\text { Hasil Belajar } \\
\text { Ranah } \\
\text { Keterampilan }\end{array}$ & Keterampilan Eksperimen & .141 & 20 & $.200^{*}$ & .926 & 20 & .130 \\
\cline { 2 - 8 } & Keterampilan Kontrol & .104 & 20 & $.200^{*}$ & .980 & 20 & .940 \\
\hline
\end{tabular}

Berdasarkan Tabel 9 diperoleh nilai signifikan baik pada kelas eksperimen maupun kelas kontrol lebih besar dari 0,05 sehingga dapat dikatakan bahwa data berdistribusi normal. Selanjutnya dilakukan uji independent sample $t$ test untuk mengetahui ada tidaknya perbedaan yang signifikan antara nilai keterampilan kelas eksperimen dan kelas kontrol. Sebelum melakukan uji independent sample t test maka perlu adanya hipotesis statistik untuk menentukan kesimpulan dari uji tersebut. Hipotesis statistik dari penelitian ini yaitu:

$\mathrm{H}_{0}$ : tidak terdapat perbedaan rata-rata hasil belajar siswa ranah keterampilan pada kelas eksperimen dan kelas kontrol

$\mathrm{H}_{1}$ : terdapat perbedaan rata-rata hasil belajar siswa ranah keterampilan pada kelas eksperimen dan kelas kontrol

Output uji independent sample t test dapat dilihat pada Tabel 10.

Tabel 10. Independent Samples Test

\begin{tabular}{|c|c|c|c|c|c|c|c|c|c|c|}
\hline & \multicolumn{2}{|c|}{$\begin{array}{l}\text { Levene's } \\
\text { Test for } \\
\text { Equality of } \\
\text { Variances }\end{array}$} & \multicolumn{7}{|c|}{ t-test for Equality of Means } \\
\hline & & \multirow[t]{2}{*}{$\mathrm{F}$} & \multirow[t]{2}{*}{ Sig. } & \multirow[t]{2}{*}{$\mathrm{t}$} & \multirow[t]{2}{*}{$\mathrm{df}$} & \multirow[t]{2}{*}{$\begin{array}{l}\text { Sig. (2- } \\
\text { tailed) }\end{array}$} & \multirow[t]{2}{*}{$\begin{array}{l}\text { Mean } \\
\text { Differe } \\
\text { nce }\end{array}$} & \multirow{2}{*}{$\begin{array}{c}\text { Std. } \\
\text { Error } \\
\text { Differe } \\
\text { nce }\end{array}$} & \multicolumn{2}{|c|}{$\begin{array}{c}95 \% \text { Confidence } \\
\text { Interval of the } \\
\text { Difference } \\
\end{array}$} \\
\hline & & & & & & & & & Lower & Upper \\
\hline \multirow{2}{*}{$\begin{array}{l}\text { Hasil Belajar } \\
\quad \text { Ranah } \\
\text { Keterampilan }\end{array}$} & $\begin{array}{c}\text { Equal } \\
\text { variances } \\
\text { assumed }\end{array}$ & 9.311 & .004 & 2.378 & 38 & . 023 & 8.750 & 3.680 & 1.300 & 16.200 \\
\hline & $\begin{array}{c}\text { Equal } \\
\text { variances not } \\
\text { assumed } \\
\end{array}$ & & & 2.378 & $\begin{array}{c}27.4 \\
11\end{array}$ & .025 & 8.750 & 3.680 & 1.205 & 16.295 \\
\hline
\end{tabular}

Berdasarkan hasil uji independent sample t test pada Tabel 10 diperoleh nilai signifikansi (Sig.) pada kolom Levene's Test for Equality of Variances sebesar 0,004 sehingga dapat dikatakan data pada ranah keterampilan bersifat tidak homogen. Tahap selanjutnya yaitu membaca baris Equal variances not assumed pada kolom $t$-test for Equality of Means yang menunjukkan bahwa nilai Sig. (2-tailed) sebesar 0,025 yang artinya nilai signifikansi < 0,05 sehingga $\mathrm{H}_{0}$ ditolak dan $\mathrm{H}_{1}$ diterima. Dengan demikian dapat disimpulkan bahwa ada 
perbedaan hasil belajar siswa ranah keterampilan antara kelas eksperimen dan kelas kontrol karena pembelajaran e-learning menggunakan platform Schoology. Setelah mengetahui data terdapat perbedaan, selanjutnya perlu dilakukan uji $\mathrm{t}$ - pihak kanan. Hipotesis statistik dan kriteria uji statistik pada ranah keterampilan ini sama halnya dengan ranah pengetahuan. Hasil uji t - pihak kanan pada hasil belajar ranah pengetahuan dapat dilihat pada Tabel 11.

Tabel 11. Hasil uji t - pihak kanan hasil belajar ranah keterampilan

\begin{tabular}{|c|c|c|c|}
\hline Kelas & Rata-rata & \multirow{2}{*}{$\mathrm{t}_{\text {hitung }}$} & $\mathrm{t}_{\text {tabel }}$ \\
\cline { 1 - 2 } Kelas Eksperimen & 72 & \multirow{2}{*}{2.378} & \multirow{2}{*}{1.703} \\
\hline Kelas Kontrol & 63 & & \\
\hline
\end{tabular}

Tabel 11 menunjukkan bahwa diperoleh uji $\mathrm{t}$ - pihak kanan hasil belajar ranah keterampilan. Nilai $t_{\text {tabel }}$ pada tabel distribusi t dengan taraf signifikansi 0,05 sebesar 1,703, sedangkan hasil perhitungan untuk $t_{\text {hitung }}$ sebesar 2,378. Hasil perhitungan tersebut menunjukkan bahwa $t_{\text {hitung }}>\mathrm{t}_{\text {tabel }}$ maka dapat dinyatakan bahwa $\mathrm{H}_{0}$ ditolak dan $\mathrm{H}_{1}$ diterima yang artinya nilai rata-rata kelas eksperimen lebih baik dibandingkan dengan kelas kontrol. Pernyataan tersebut sesuai dengan hasil penelitian yang telah dilakukan oleh Kusumantara et al. (2017:134) bahwa kelas eksperimen yang pembelajarannya menggunakan Schoology memperoleh hasil belajar yang lebih tinggi dibandingkan dengan kelas kontrol, hal tersebut dikarenakan siswa bukan hanya sekedar mendengar atau menyimak materi dari guru melainkan siswa turut aktif dalam proses pembelajaran yang mana kondisi tersebut sesuai bagian dari karakteristik e-learning. Hasil penelitian dari Tigowati et al. (2017:55) menyimpulkan bahwa Schoology berpengaruh terhadap hasil belajar siswa yang diperkuat oleh hasil wawancaranya dengan siswa yang menyatakan bahwa pembelajaran menggunakan Schoology menjadikan lebih semangat, tidak membuat bosan, mempermudah pengerjaan tugas, lebih mandiri belajar, dan mudah memahami materi-materi pelajaran. Hasil penelitian yang dilakukan oleh Utami et al. (2017:84) menyimpulkan bahwa penggunaan e-learning dengan Schoology berpengaruh signifikan terhadap hasil belajar siswa. Hal tersebut dipengaruhi oleh beberapa kelebihan Schoology yaitu dapat menjadi wadah kelompok kolaboratif siswa dengan guru. Selain itu, Schoology juga dapat digunakan pada web browser apa saja dan mampu terhubung dengan berbagai aplikasi lainnya.

\section{PENUTUP}

Hasil penelitian menunjukkan bahwa penggunaan Schoology melalui pembelajaran e-learning memiliki pengaruh terhadap kemandirian belajar dan hasil belajar. Kelas eksperimen memiliki rata-rata nilai lebih tinggi dibandingkan kelas kontrol baik pada kemandirian belajar maupun hasil belajar.

Berdasarkan hasil penelitian, peneliti memberikan rekomendasi bagi guru dalam memanfaatkan LMS Schoology untuk pengelolaan kelas yang lebih menarik serta meningkatkan kemandirian belajar dan hasil belajar siswa. Bagi peneliti selanjutnya dapat meneliti lebih lanjut terkait pengaruh Schoology pada materi pelajaran lain terhadap variabel yang lebih luas. 


\section{UCAPAN TERIMA KASIH}

Penelitian ini tidak dapat terselesaikan tanpa dukungan dan bantuan dari berbagai pihak. Peneliti mengucapkan terima kasih kepada Kepala Sekolah dan Guru Pamong yang telah mengizinkan penelitian serta memberikan arahan dan bimbingan sehingga dapat menjalankan penelitian dengan lancar.

\section{DAFTAR PUSTAKA}

Bungsu, T.K., M. Vilardi., P. Akbar., dan M. Bernard. 2019. Pengaruh Kemandirian Belajar terhadap Hasil Belajar Matematika di SMKN 1 Cihampelas. Journal on Education. 1(2): 382-389.

Dinatha, N.M., dan D.N.L. Laksana. 2017. Nilai Nilai Karakter dalam Pembelajaran IPA di Perguruan Tinggi. $2^{\text {nd }}$ Annual Proceeding. November 2017. STKIP Citra Bakti: 177187.

Erviani, F.R., Sutarto., dan Indrawati. 2016. Model Pembelajaran Instruction, Doing, dan Evaluating (MPIDE) Disertai Resume dan Video Fenomena Alam dalam Pembelajaran Fisika di SMA. Jurnal Pembelajaran Fisika. 5(1): 53-59.

Handayanti, A., Indrawati, dan I. Wicaksono. 2020. Penggunaan Media PHET (Physics Education Technology) pada Pembelajaran Getaran dan Gelombang terhadap Kemampuan Berpikir Kritis dan Hasil Belajar Siswa SMP. OPTIKA (Jurnal Pendidikan Fisika). 4(2): 63-72.

Juniati, N.W., dan I.W. Widiana. 2017. Penerapan Model Pembelajaran Inkuiri untuk Meningkatkan Hasil Belajar IPA. Jurnal Ilmiah Sekolah Dasar. 1(1): 20-29.

Karlina, N., Karlimah., dan Sumardi. 2018. Pengaruh Media Bagan Garis Waktu (Time Line Chart) terhadap Hasil Belajar Siswa dalam Materi Persiapan Sampai Detik-detik Proklamasi di SD. PEDADIDAKTIKA: Jurnal Ilmiah Pendidikan Guru Sekolah Dasar. 5(1): 53-61.

Kusmantara, K.S., G.S. Santyadiputra., dan N. Sugihartini. 2017. Pengaruh E-learning Schoology Terhadap Hasil Belajar Simulasi Digital dengan Model Pembelajaran SAVI. Jurnal Pendidikan Teknologi dan Kejuruan. 14(2): 126-135.

Mayasari, F., S. Santoso., dan D. Octoria. 2016. Upaya Meningkatkan Kemandirian Belajar Siswa melalui Penerapan Blended Learning Berbantuan Quipper School. Jurnal "Tata Arta" UNS. 2(3): 148-161.

Misbah., W.A. Pratama. S. Hartini., dan D. Dewantara. 2018. Pengembangan E-Learning Berbasis Schoology pada Materi Impuls dan Momentum untuk Melatihkan Literasi Digital. Pancasakti Science Education Journal. 3(2): 109-114.

Murni, C.K., dan R. Harimurti. 2016. Pengaruh E-learning Berbasis Schoology terhadap Peningkatan Hasil Belajar Siswa dalam Materi Perangkat Keras Jaringan Kelas X TKJ 2 pada SMK Negeri 3 Buduran, Sidoarjo. Jurnal IT-Edu. 1(1): 86-90.

Nurbani, D., D. Gusrayani., dan A.K. Jayadinata. 2016. Pengaruh Model Learning Cycle terhadap Keterampilan Proses Sains Siswa SD Kelas IV pada Materi Hubungan antara Sifat Bahan dengan Kegunaannya. Jurnal Pena Ilmiah. 1(1): 211-220.

Pertiwi. U.D., R.D. Atamti., dan R. Ismawati. 2018. Pentingnya Literasi Sains pada Pembelajaran IPA SMP Abad 21. Indonesian Journal of Natural Science Education (IJNSE). 1(1): 24-29.

Tigowati, A. Efendi., dan C.W. Budiyanto. 2017. E-learning Berbasis Schoology dan Edmodo: ditinjau dari Motivasi dan Hasil Belajar Siswa SMK. Elinvo (Electronics, Informatics, and Vocational Education). 2(1): 49-58. 
Tsaniyah, S.F., H.D. Ayu., dan H.Y. Pratiwi. 2019. Pengaruh Model Blended Learning Menggunakan Schoology terhadap Prestasi Belajar ditinjau dari Kemandirian Belajar Siswa. Jurnal Terapan Sains \& Teknologi. 1(1): 71-77.

Utami, R.P., U. Rosidin., dan I. Wahyudi. 2017. Pengaruh Penggunaan E-learning dengan Schoology Materi Gravitasi Newton Terhadap Hasil Belajar Siswa. Jurnal Pendidikan Fisika. 5(2): 81-91.

Ulva, N.L., S. Kantun., dan J. Widodo. 2017. Penerapan E-learning dengan Media Schoology untuk Meningkatkan Motivasi dan Hasil Belajar Siswa pada Kompetensi Dasar Mendeskripsikan Konsep Badan Usaha dalam Perekonomian Indonesia. Jurnal Pendidikan Ekonomi: Jurnal Ilmiah Ilmu Pendidikan, Ilmu Ekonomi, dan Ilmu Sosial. 11(2): 96-102.

Wicaksono, I., B. Jatmiko., dan T. Prastowo. 2015. Pengembangan Perangkat Pembelajaran Fisika Model Learning Cycle 5E untuk Meningkatkan Pemahaman Konsep Siswa pada Materi Fluida Statis. Pendidikan Sains Pascasarjana Universitas Negeri Surabaya. 4(2): 518-524.

Yani, R., Indrawati., dan I. Wicaksono. 2019. Efektivitas Penerapan Desain Pembelajaran IPA Terpadu Tipe Webbed pada Kurikulum 2013 Revisi untuk Siswa SMP Kelas VII. Seminar Nasional Pendidikan Fisika 2019 4(1). 17 November 2019. FKIP EProceeding: 173-177. 